\title{
PRZEKSZTALCENIA STRUKTURALNE W PROCESIE ROZWOJU GOSPODARCZEGO: MODYFIKACJE I ROZSZERZENIA
}

\section{WPROWADZENIE}

Gospodarki nie tylko rosna, ale także zmieniają swoją strukturę w miarę rozwoju gospodarczego (mierzonego konwencjonalnie poziomem PKB per capita). W miarę jak rośnie poziom PKB per capita, zmienia się przede wszystkim struktura produkcji i zatrudnienia. Zmiany strukturalne są $\mathrm{w}$ istocie procesem ciagłym, niemniej w ramach trwałego procesu przemian strukturalnych należałoby wyróżnić dwie fazy, czy dwa okresy, które przynoszą bardziej znaczące - nie tylko ilościowe - przekształcenia w gospodarce. Z tego też powodu warte są bardziej szczegółowej analizy.

Autor niniejszego artykułu jest zdania, że pierwsza z tych faz, tzn. faza industrializacji, jest znacznie lepiej rozpoznana teoretycznie i zbadana empirycznie niż druga. Pierwsza faza dotyczy zmian w strukturze wytwórczości, które polegają na przejęciu roli dominującego sektora - napędzającego wzrost gospodarczy - przez sektor przemysłu przetwórczego. Dotyczy to zarówno ilościowych zmian w strukturze produkcji, jak i determinant tychże zmian. Mamy za sobą kilkadziesiąt lat badań, rozważań teoretycznych i dyskusji na temat i jednych, i drugich.

Inaczej wygląda sytuacja drugiej fazy przekształceń. Druga faza dotyczy bowiem przekształceń, które stały się częstsze, a przez to lepiej zauważalne i skłaniające do uogólnień, dopiero w okresie ostatnich paru dziesięcioleci. Jest to faza przekształceń strukturalnych, która polega na kolejnej zmianie roli dominującego sektora napędzającego wzrost gospodarczy. Tę rolę przejmuje od sektora przemysłu przetwórczego (sub)sektor usług intensywnie wykorzystujacy wysoko wykwalifikowaną siłę roboczą (czy, nieco inaczej definiując, kapitał ludzki).

Ta kolejna faza przekształceń strukturalnych jest wyraźnie mniej zbadana niż poprzednia - i to nie tylko z racji jej relatywnej nowości, lecz także z dwóch innych powodów. Po pierwsze, nie mamy do czynienia z przejęciem dominującej roli przez kolejny sektor gospodarki, lecz tylko przez jego część, tzn. przez nowoczesne usługi intensywnie wykorzystujace kapitał ludzki. Usługi tradycyjne, mające spory udział w produkcji i zatrudnieniu, są słabo powiazane z dynamiką nowoczesnych usług w gospodarce. Po drugie wreszcie, część sek- 
tora usług o dużym nasyceniu kapitałem ludzkim pozostaje w ścisłej interakcji z nielicznymi zaawansowanymi technologicznie branżami przemysłu przetwórczego, co również zmniejsza czytelność dokonujących się przekształceń.

\section{INDUSTRIALIZACJA: WZORCE PRZEKSZTALCEŃ STRUKTURALNYCH I ODCHYLENIA OD TYCHŻE WZORCÓW}

W literaturze przedmiotu zaczyna się zwykle jej prezentację od prac Simona Kuznetsa, laureata Nagrody Nobla w dziedzinie ekonomii. Najczęściej cytowane jego prace są poświęcone wzrostowi gospodarczemu krajów świata zachodniego i towarzyszacym temu wzrostowi przemianom strukturalnym ${ }^{1}$. Kuznets podkreślał w nich, że rozwinięte gospodarczo kraje zachodnie osiagnęły bardzo podobną strukturę ekonomiczną (produkcji, zatrudnienia itd.), mimo iż proces uprzemysłowienia zaczynał się w poszczególnych krajach w różnym czasie i przebiegał z różna prędkością. Zwracał też uwagę na to, że kraje na niskim poziomie rozwoju (mierzonym PKB per capita) również charakteryzowały się podobnymi do siebie strukturami. W tych pierwszych dominował przemysł, w tych drugich - rolnictwo.

Pałeczkę w budowaniu teorii przemian strukturalnych, wówczas koncentrujących się na industrializacji, przejęła następnie grupa ekonomistów skupionych wokół Hollisa Chenery'ego: Moises Syrquin, Lance Taylor, Tsunehiko Watanabe czy Larry Westphal. Budujac modele ekonometryczne i prowadząc szeroko zakrojone badania statystyczne, przebadali oni dziesiątki krajów słabo rozwiniętych oraz tych, które zapoczątkowały lub zaawansowały już proces uprzemysłowienia, a następnie przedstawili określone wzorce przekształceń strukturalnych w procesie industrializacji, wiążąc wspólne, ujednolicające cechy tych przekształceń z procesem wzrostu gospodarczego ${ }^{2}$.

Natomiast zróżnicowania strukturalne między krajami przypisywali głównie dwóm zmiennym: 1) zasobom mineralnym kraju oraz 2) wielkości (skali) gospodarki mierzonej liczbą ludności (przy czym do krajów dużych zaliczali już takie, których ludność przekraczała $15 \mathrm{mln}$ osób). Trzecią zmienną różnicująca zajmiemy się później, gdy rozważać będziemy determinanty wzrostu gospodarczego i przemian strukturalnych.

Te wspólne, ujednolicające wzorzec zmian strukturalnych, cechy procesu wzrostu gospodarczego powoduja - jak wynikało z tych badań - wzrost udziału przemysłu przetwórczego z ok. 7,5-10 do 30-40\% PKB w punkcie szczytowym

${ }^{1}$ Zob. S. Kuznets, Modern Economic Growth: Rate, A Structure and Speed, Yale UP, New Haven 1966 oraz idem, Economic Growth of Nations: Total Output and Production Structure, The Belknap Press, Cambridge, Mass., 1966 (wyd. polskie: Wzrost gospodarczy narodów, PWE, Warszawa 1976) oraz seria artykułów w „Economic Development and Cultural Change” w latach pięćdziesiątych i sześćdziesiatych XX w.

${ }^{2}$ Najbardziej znana praca to książka: H. B. Chenery, M. Syrquin, Patterns of Development 1950-1970, Oxford UP, London 1975. 
tegoż udziału. Ponieważ większość prac wspomnianych autorów opublikowano w latach sześćdziesiątych i siedemdziesiątych XX w., więc w tym okresie nie byli oni w stanie zaobserwować pojawienia się punktu przegięcia, tzn. w tym przypadku okresu (czy poziomu PKB per capita), od którego udział przemysłu przetwórczego w PKB zaczyna się zmniejszać. W rzeczywistości proces zmniejszania się udziału przemysłu przetwórczego zaobserwowano wówczas zaledwie w kilku rozwiniętych gospodarczo krajach zachodnich.

Późniejsze badania uzupełniły te obserwacje i wykazały, że trwały proces przekształceń strukturalnych powoduje zmianę tendencji w postaci zmniejszania się udziału przemysłu przetwórczego na pewnym, na ogół już wysokim, poziomie rozwoju gospodarczego. Tak więc krzywoliniowy udział przemysłu przetwórczego w PKB i zatrudnieniu należy do cech ogólnych przemian strukturalnych. Tę krzywoliniowość przedstawia wykres 1.

Wykres 1

Udział przemysłu przetwórczego w procesie rozwoju gospodarczego

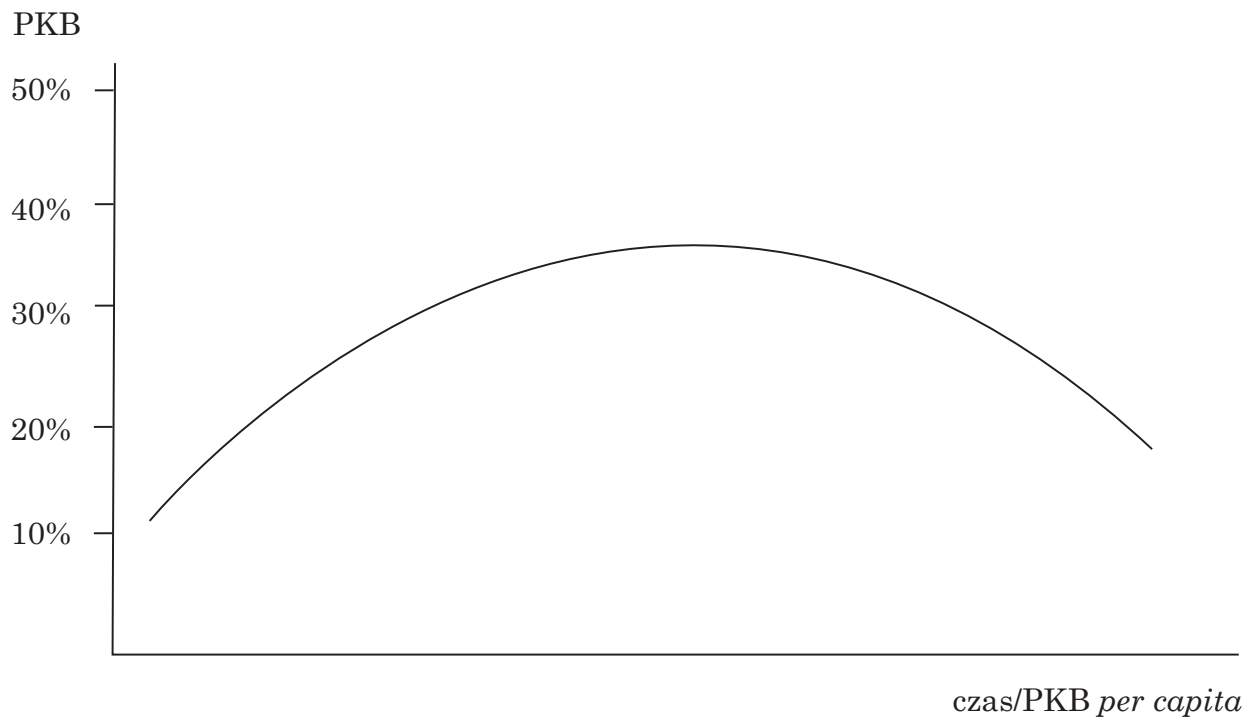

Źródło: opracowanie własne.

Krzywa zmian udziału przemysłu przetwórczego w PKB (i zbliżona do niej kształtem krzywa zmian udziału przemysłu przetwórczego w zatrudnieniu ogółem) z prac wzmiankowanych wcześniej autorów przedstawia pewien typ idealny przekształceń strukturalnych odnoszący się do wszystkich krajów. Kraje różnią się jednak między soba, choćby wymienionymi wyżej cechami różnicujacymi, jak posiadane zasoby naturalne czy wielkość gospodarki. Badania Chenery’ego, Syrquina i innych wykazały określone odmienności strukturalne w procesie wzrostu gospodarczego. 
Otóż kraje duże i średnie (tak bowiem należałoby określić kraje o liczbie ludności powyżej $15 \mathrm{mln}$ ), nawet jeśli są słabo rozwinięte (o bardzo niskim PKB na mieszkańca), charakteryzują się dostateczną wielkością rynku, pozwalajaca na opłacalne powstawanie firm w gałęziach przemysłu przetwórczego, w których występują efekty skali. Na przykład pierwsza huta żelaza i stali powstała w Indiach już na przełomie XIX i XX w.! W związku z tym, że obok gałęzi tradycyjnych, powstających na niskim poziomie rozwoju, w krajach dużych powstają też gałęzie, w których występuja efekty skali (hutnictwo, przemysł cementowy, chemia wielkotonażowa i in.), udział przemysłu przetwórczego rośnie w krajach dużych i średnich szybciej niż w krajach małych. Oznacza to wyższy udział przemysłu przetwórczego w PKB na niższym poziomie PKB na mieszkańca.

Kraje mniejsze różnią się od krajów dużych i średnich trajektorią udziału przemysłu przetwórczego w relacji do PKB per capita, ale także różnią się między sobą. Zmienną różnicujaccą są przede wszystkim zasoby surowców mineralnych (w tym paliw). Tak więc $\mathrm{w}$ pracach wymienionej grupy autorów kraje mniejsze dzielą się na dwie grupy:

- kraje mniejsze zorientowane na przemysł przetwórczy, na ogół pozbawione znaczacych zasobów surowców i paliw oraz

- kraje mniejsze bogate w surowce i paliwa mineralne.

Te pierwsze, z racji niewielkiego rynku wewnętrznego i braku możliwości wykorzystania zasobów mineralnych w eksporcie, zmuszone są do wczesnego rozwoju przemysłu przetwórczego, aby zaspokoić nie tylko potrzeby krajowe, lecz także pewien poziom potrzeb importowych gospodarki krajowej (eksport produktów rolnych jest niewystarczający w tym względzie). Jeśli uda im się przeprowadzić pewne zmiany instytucjonalne sprzyjające industrializacji, powoduje to szybki wzrost produkcji i zatrudnienia w przemyśle przetwórczym, a następnie także wzrost eksportu.

Oczywiście, w związku z niskim poziomem rozwoju gospodarczego kraje te koncentrują swoją produkcję, a w jeszcze większym stopniu eksport, na wyrobach wymagających dużego wkładu pracy prostej. Czyli, zgodnie z klasyczną teorią handlu międzynarodowego w wersji Heckschera-Ohlina, specjalizują się w wyrobach pracochłonnych.

Trajektoria udziału przemysłu przetwórczego w PKB tych krajów różni się od tejże trajektorii krajów dużych i średnich. Udział przemysłu przetwórczego $\mathrm{w}$ tych ostatnich rośnie szybciej na wczesnym etapie uprzemysłowienia z powodów wymienionych wyżej. W krajach mniejszych o orientacji na przemysł przetwórczy udział ten jest niższy (tzn. rośnie wolniej) na tym etapie, ale na późniejszych etapach industrializacji rośnie szybciej i punkt przegięcia, czyli najwyższy udział w PKB, przy którym następuje spadek tego udziału, jest w procentach $\mathrm{PKB}$ - taki sam lub nawet nieco wyższy niż w krajach dużych i średnich. Oczywiście we wszystkich krajach uprzemysławiających się przez cały czas zachodzą zmiany w strukturze gałęziowej przemysłu przetwórczego w kierunku większego udziału gałęzi kapitałochłonnych (a później jeszcze udziału gałęzi wymagających dużej ilości kapitału ludzkiego; tych ostatnich 
przemian nie podejmowano w prezentowanym tutaj nurcie literatury przedmiotu). Następują więc zmiany w korzyściach komparatywnych w procesie rozwoju gospodarczego.

Kraje mniejsze, bogate $\mathrm{w}$ surowce i paliwa mineralne, różnią się bardzo trajektorią udziału przemysłu przetwórczego od dwóch pierwszych grup krajów. Po pierwsze, z racji eksportowalnych bogactw naturalnych kraje te nie czują presji w kierunku rozwoju przemysłu przetwórczego i eksportu jego wyrobów. W rezultacie transformacja strukturalna przebiega tam znacznie wolniej, a udział przemysłu przetwórczego w PKB i udział jego wyrobów w eksporcie zaczynają rosnąć wyraźniej dopiero na późnym etapie transformacji. Ich poziom PKB per capita jest wówczas już dość wysoki, w rezultacie czego nie dokonują one na ogół specjalizacji w produkcji wyrobów pracochłonnych, lecz raczej kapitałochłonnych, często związanych z przetwórstwem posiadanych zasobów surowców i paliw. Różnice między trajektoriami udziału przemysłu przetwórczego krajów dużych i średnich oraz obu grup krajów mniejszych przedstawia wykres 2. Powyższe konkluzje dotyczą najważniejszych uogólnień, interesujących z perspektywy celów tego artykułu, choć oczywiście, badania tego nurtu przyniosły także szereg innych jeszcze obserwacji dotyczących przemian strukturalnych.

Wykres 2

Udział przemysłu przetwórczego w procesie rozwoju gospodarczego według grup krajów

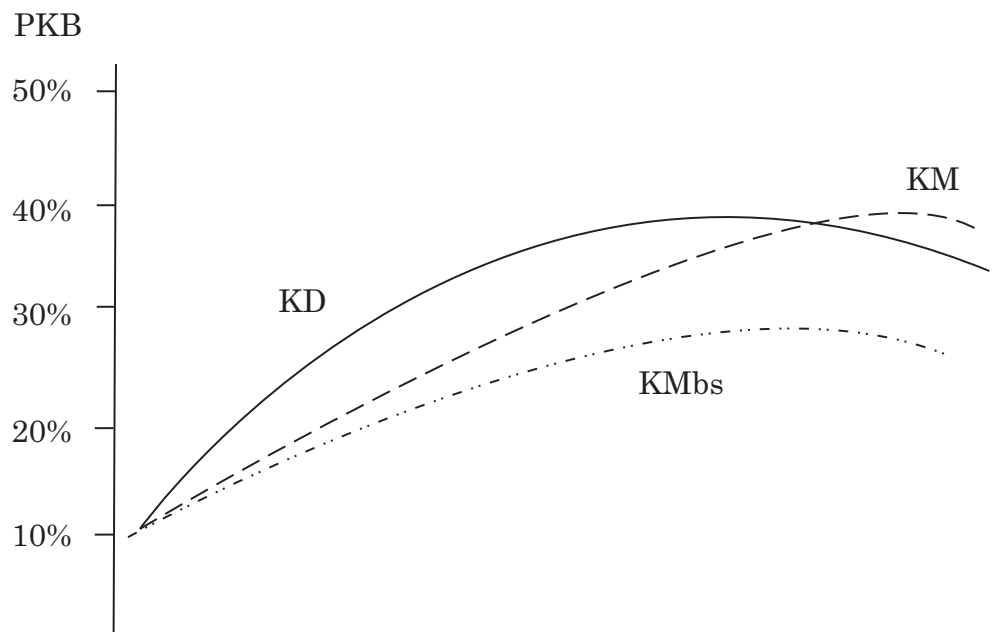

czas/PKB per capita

$\mathrm{KD}$ - kraje duże
$\mathrm{KM}$ - kraje mniejsze
$\mathrm{KMbs}$ - kraje mniejsze bogatsze w surowce i paliwa mineralne

Źródło: opracowanie własne. 


\section{INDUSTRIALIZACJA A JEJ DETERMINANTY}

Uogólnienia na temat przekształceń strukturalnych ukształtowane zostały (z wyjątkiem Simona Kuznetsa) przez ekonomistów o silnie interwencjonistycznej filozofii ekonomicznej, należących do nurtu tzw. development economics. Stąd brały się właśnie ich określone preferencje w kwestii strategii rozwojowej. W szczególności dotyczy to interpretacji trzeciej zmiennej oddziałującej na wzrost gospodarczy, a w konsekwencji i na zmiany strukturalne, tzn. instytucji gospodarczych i polityki prowadzonej w ramach tychże instytucji.

Autor niniejszego artykułu też uważa instytucje gospodarcze i politykę prowadzoną w ramach tychże instytucji za niezwykle ważne dla procesu rozwoju gospodarczego. Dał on wyraz temu poglądowi m.in. w książce: The Distorted World of Soviet-Type Economies (1988), w której udowadniał wpływ czynników instytucjonalnych na zniekształcenia wzrostu gospodarczego i przemian strukturalnych w gospodarkach komunistycznych. Jednym z przykładów tych zniekształceń był wyraźny przerost udziału przemysłu w strukturze PKB i zatrudnienia tych krajów w stosunku do typu idealnego udziału przemysłu przetwórczego (pokazuje to wykres 3).

Wykres 3

Wpływ czynników instytucjonalnych

na udział przemysłu wytwórczego w procesie rozwoju gospodarczego

PKB

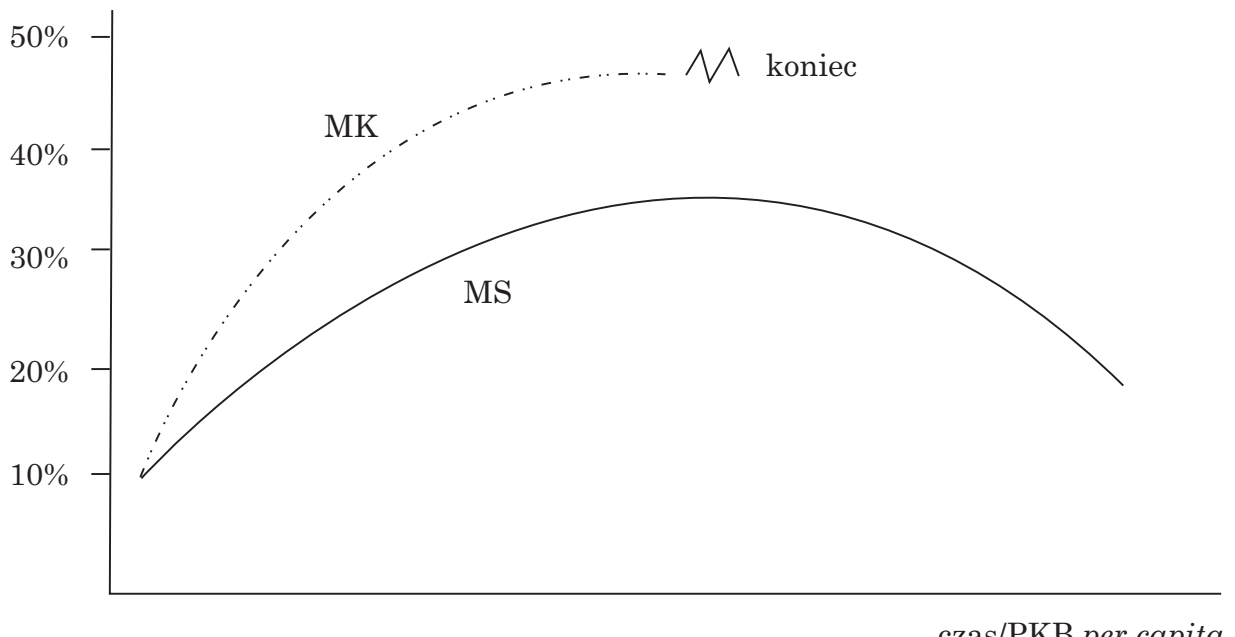

MK - model komunistyczny (aż do końca jego istnienia, czyli l. 1989-1991)

MS - standardowy model (wzorzec) przemian strukturalnych 
Warto też zasygnalizować czytelnikom, że inne determinanty różnicujące nie odgrywały żadnej roli w tym względzie w przypadku krajów komunistycznych. Zniekształcenia strukturalne w postaci elephantiasis przemysłu przetwórczego były bardzo podobne i w kraju dużym, tzn. Związku Sowieckim, i w krajach małych i średnich. Tak samo były one podobne w kraju niezwykle bogatym w surowce mineralne i paliwa (tymże samym Związku Sowieckim) i pozostałych europejskich krajach komunistycznych, zdecydowanie uboższych w bogactwa mineralne.

Chenery i inni wzmiankowani wyżej autorzy, należący do nurtu development economics, mieli inne wyobrażenie o strategii rozwojowej. Uważali oni, że to właśnie silnie interwencjonistyczna strategia gospodarki kierowanej z centrum, ograniczająca oddziaływanie mechanizmu kapitalistycznego rynku oraz kontrolująca relacje danej gospodarki z zagranica, jest warunkiem sine qua non zapoczątkowania procesu rozwoju.

Historia gospodarcza krajów słabiej rozwiniętych nie przyznała im racji. Hongkong, a potem Tajwan i Korea Południowa, albo nie wprowadziły mechanizmu zaawansowanego interwencjonizmu w ogóle (ten pierwszy), albo stosunkowo wcześnie od niego odeszły (dwa ostatnie), natomiast procesy rozwojowe w ich wykonaniu przebiegały znacznie szybciej i okazały się przypadkami wielkiego sukcesu. Wzrost gospodarczy był w tych krajach niezwykle szybki i w efekcie interesujące nas tutaj przemiany w strukturze produkcji również przebiegały tam w szybkim tempie. Mało tego, że strategie rozwojowe tych krajów (dodać można do nich Singapur) były znacznie mniej interwencjonistyczne, to jeszcze udowodniły, iż to właśnie otwarcie na sygnały z rynku światowego i wykorzystanie korzyści komparatywnych (dynamiczny eksport wyrobów wymagajacych pracy prostej), a nie ograniczanie tychże kontaktów, jest podstawą sukcesu w rozwoju gospodarczym. Dlatego m.in. w późniejszych pracach kategoryczne stwierdzenia dotyczące strategii rozwojowej i oceny roli wymiany międzynarodowej w tejże strategii zostały stonowane przez tych autorów ${ }^{3}$.

Pojawiły się także inne modyfikacje lub rozszerzenia w stosunku do wzorca przemian strukturalnych prezentowanego przez Kuznetsa, a następnie Chenery'ego i jego współpracowników. Everett E. Hagen w kolejnych wydaniach swojego podręcznika ${ }^{4}$ podkreślał, że industrializacja nie rozpoczyna się od budowy wielkich fabryk, wytwarzających duże ilości produktów przemysłowych. Przeciwnie, „rudymentarny kompleks przemysłowy”, jak to nazywa Hagen, powstaje wtedy, gdy zwiększa się liczba drobnych przedsiębiorców, którzy np. wytwarzają różne produkty, ale używają tej samej technologii albo tych samych materiałów i półfabrykatów. W rezultacie pojawiają się nowe możliwości dostaw standaryzowanych półfabrykatów lub wytwarzania i serwisowania prostych maszyn i urządzeń.

Stąd np. tak mało atrakcyjne medialnie czy politycznie produkcyjne przedsięwzięcia, jak mielenie zbóż w młynach napędzanych parą lub elektrycznoś-

${ }^{3}$ Zob. np. H. B. Chenery, Transitional Growth and World Industrialisation, w: B. Ohlin et al. (red.), The International Allocation of Economic Activity, Macmillan, London 1977.

${ }^{4}$ Zob. np. Economics of Development, wyd. 5, R. D. Irwin, Homewood, Ill., 1985. 
cia, czy mechanizacja przędzenia i tkania, mogą dać impuls do pojawienia się lokalnego producenta odpowiednich maszyn i/lub ich części. Wszystko zależy od ilości takich drobnych producentów, a więc i od skali pojawiającego się popytu. Podobną rolę odgrywać może rozpoczęcie produkcji cegieł, dachówek i in. wyrobów według standaryzowanych technologii w przemysłowych cegielniach. Tak więc, według Hagena, standaryzowana produkcja przemysłowa pojawia się na dość wczesnym poziomie rozwoju.

Warto podkreślić tezy Hagena z perspektywy interesujących nas tutaj determinant rozwoju gospodarczego. Skoro uprzemysłowienie zaczyna się od owych prostych przedsięwzięć, podejmowanych przez przedsiębiorców w określonym momencie spontanicznego procesu przemian w gospodarce, interwencjonistyczna strategia rozwojowa nie jest w tym procesie punktem startowym. Wpływać ona może - na dobre i na złe (vide zniekształcenia w gospodarkach komunistycznych) - na spontaniczny proces rozwoju gospodarczego, ale nie jest ani warunkiem koniecznym, ani wystarczającym tegoż procesu.

Empiryczną weryfikacją tezy Hagena są prace wskazujące, że proces intensywnego wzrostu gospodarczego, rozumianego jako trwały wzrost PKB per capita, rozpoczyna się wcześniej, niż to sobie wyobrażali zwolennicy silnie interwencjonistycznej strategii rozwojowej, czy to w wersji development economics, czy tė̇ w wersji skrajnej, czyli komunistycznej gospodarki centralnie planowanej i administrowanej połaczonej ze strategią „stromego podejścia”. Współpracownik Everetta Hagena, Lloyd G. Reynolds, udowodnił, że wzrost intensywny (wzrost PKB per capita) rozpoczął się w wielu krajach, poczynając od połowy XIX w.

Z kolei kraje słabiej rozwinięte, a więc inne niż kraje świata zachodniego, a były to w latach 1840-1913 (czyli już na długo przed I wojna światowa) aż 23 państwa, weszły na drogę intensywnego wzrostu gospodarczego, poczynając od Chile ok. 1840 r., a kończąc na Korei ok. 1910 r. W okresie dwóch wojen światowych i depresji gospodarczej taki proces zapoczątkowały już jednak zaledwie 3 kraje. W swojej książce Reynolds ${ }^{5}$ wskazał też na procesy zwiększania się udziału przemysłu przetwórczego w tych krajach. I nie jest to odkryciem zaskakujacym. Skądś bowiem musiał brać się udział przemysłu przetwórczego w gospodarce krajów słabiej rozwiniętych rzędu 7,5-10\% PKB na starcie procesu przemian strukturalnych, który znajdujemy w kalkulacjach Chenery'ego i jego współpracowników!

Autor niniejszego artykułu dostrzega jednakże istnienie określonych problemów teoretycznych w kwestii determinant procesów rozwoju gospodarczego w odniesieniu do industrializacji. Otóż doświadczenia tzw. azjatyckich tygrysów (Hongkongu, Tajwanu, Korei Płd., Singapuru), wzmiankowane powyżej, wskazały na znaczenie wyższego poziomu wolności gospodarczych dla sukcesu industrializacji. To właśnie wyższy poziom wolności gospodarczych, a nie kierowanie gospodarką z centrum i kontrola wymiany z zagranica, zadecydowały o sukcesie azjatyckich tygrysów, a następnie krajów słabo rozwiniętych, które zmieniły swoją strategię w tym samym kierunku, co wspomniane tygrysy. Wcześniej zaś właśnie owe wolności gospodarcze zadecydowały o udanej industrializacji krajów zachodnich.

\footnotetext{
${ }^{5}$ Economic Growth in the Third World, Yale UP, New Haven 1985.
} 


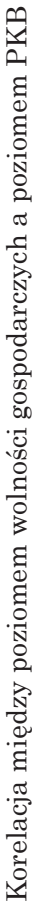

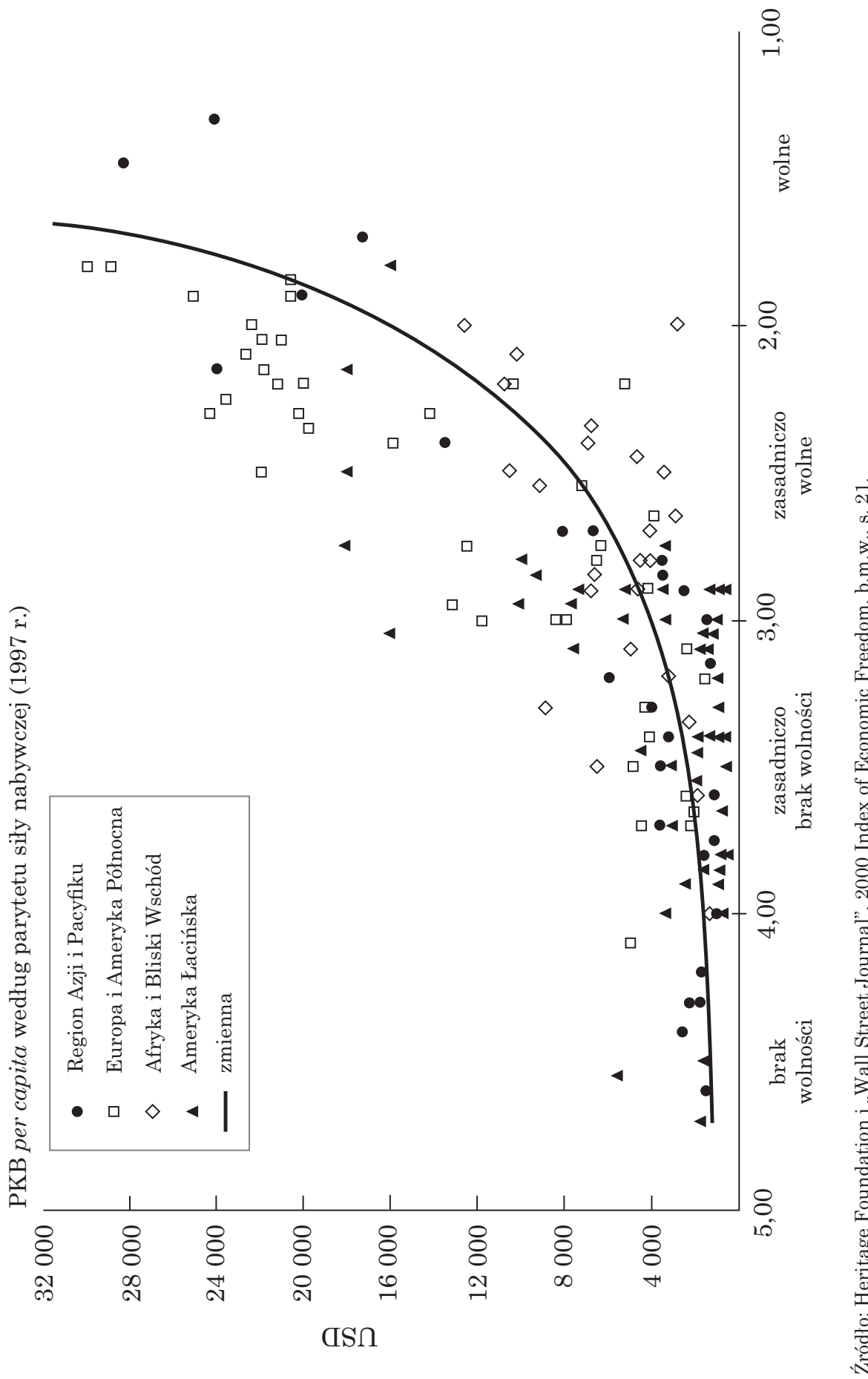


W różnych rankingach wolności gospodarczej jednakże szereg krajów, które osiąnęły sukcesy w postaci szybkiego wzrostu gospodarczego per capita oraz zarejestrowały towarzyszące temu szybkiemu wzrostowi gospodarczemu zmiany instytucjonalne, nie wykazywało się bynajmniej wysokim poziomem wolności gospodarczych. Weźmy np. Index of Economic Freedom z 2011 r. i zobaczmy, jak oceniane są pod tym względem szybko rosnące w dekadzie 2001-2010 kraje BRIC. Okaże się, że Brazylia zajmuje w tym rankingu 113 miejsce, Rosja - aż 143, Indie - 124, a najszybciej rosnące na świecie Chiny - miejsce 135. Z innych szybko rosnących gospodarek o niskim poziomie wolności gospodarczych (i często dyktatorskich rządach), ale o szybkim wzroście gospodarczym wymienić można jeszcze Wietnam zajmujacy 139 miejsce, Filipiny - 115 czy Azerbejdżan - 92 .

Za dużo jest więc tych odchyleń od normy, za jaką uważamy dodatnia korelację między poziomem wolności gospodarczych a poziomem PKB na mieszkańca, który jest efektem wzrostu gospodarczego w dłuższym okresie. Istnieje więc konflikt między realiami wcale dużej grupy krajów a powyższą korelacja populacji krajów, która reprezentuje wykres 4 . Wyłom w powyższych uogólnieniach uczynił niedawno Francis Fukuyama. W swojej najnowszej książce: The Origins of Political Order ${ }^{6}$, w rozdziale 17, dowodzi on, że w warunkach współczesnej gospodarki, z jej silnym oddziaływaniem zmian technologicznych, instytucje gospodarki nie muszą być doskonałe (w sensie wysokiego poziomu wolności gospodarczych), lecz wystarczy, by były one „dostateczne" (good enough). I w ten sposób wyjaśnia sukcesy takich krajów, jak wymienione przeze mnie powyżej.

Po pewnym namyśle można zgodzić się z korektą zaproponowaną przez Fukuyamę. W końcu jeśli wziąć za przykład gospodarki komunistyczne z tak fatalna struktura bodźców, powinny one dużo wcześniej załamać się i zarejestrować absolutny regres w porównaniu z gospodarkami krajów Zachodu. Tymczasem zarejestrowały one częściej rosnący regres w zględny. To znaczy dystans w poziomie PKB per capita zaczał od pewnego momentu rosnąć i rósł aż do załamania się politycznego i gospodarczego systemu komunistycznego w Europie.

Do czynników łagodzacych wpływ różnic instytucjonalnych dodałbym tu jeszcze jedna zmienna. Mianowicie: niezwykle wnikliwe rozróżnienie, dokonane przez Deepaka Lala, między wzrostem, który nazywa on „smithowskim" (czyli wynikajacym z oddziaływania systemu instytucjonalnego), a „wzrostem prometejskim”, czyli wzrostem umożliwionym dzięki pojawieniu się w końcu XVIII w. możliwości pozyskiwania na masową skalę energii z paliw kopalnych ${ }^{7}$. I istotnie, to właśnie te możliwości (marnotrawnego) wykorzystywania źródeł energii przez kraje komunistyczne umożliwiały pewien, zniekształcony w dodatku, ich wzrost gospodarczy. Sam smithowski

${ }^{6}$ Profile Books, London 2011.

${ }^{7}$ Zob. D. Lal, Unintended Consequences. The Impact of Factor Endowments, Culture, and Politics on Long-Run Economic Performance, The MIT Press, Cambridge, Mass., 1998. 
model wzrostu, oparty na sprzyjających temu wzrostowi instytucjach, przekreślałby z góry możliwości sukcesu tych krajów w postaci długotrwałego wzrostu gospodarczego.

\section{DRUGA FAZA PRZEKSZTALCEŃ STRUKTURALNYCH: NIEDOSTATEK TEORII I PROBLEMY Z EMPIRIA}

Być może nasze rozważania w kwestii drugiej fazy przemian strukturalnych należałoby zaczaćc od śmiałego stwierdzenia, że ciagle wiemy niewiele, zarówno w kwestiach teorii, jak i badań empirycznych. Od kilku dziesięcioleci rozważa się np. zagadnienie drugiej części krzywoliniowego udziału przemysłu przetwórczego w produkcji i zatrudnieniu, czyli spadku tego udziału w miarę dalszego wzrostu PKB na mieszkańca (i następujących wewnątrz przemysłu przetwórczego zmian strukturalnych). Nie sa to jednak analizy wspomnianej we wstępie kolejnej fazy przekształceń instytucjonalnych, lecz raczej badania (czy też może nawet bia da nia) w kwestii dezindustrializacji gospodarek krajów zachodnich.

W różnych pracach naukowych kreśli się też - we wstępie do bardziej szczegółowych rozważań - model zmian strukturalnych, charakteryzujący się zmianami udziału trzech głównych sektorów gospodarki:

- trwale malejącego udziału sektora rolnictwa

- krzywoliniowego (rosnaceego, potem malejącego) udziału sektora przemysłu, oraz

- stale rosnącego udziału sektora usług.

W żadnych pracach nie stwierdza się jednak expressis verbis, że zmiany te doprowadzą do istnienia w przyszłości w krajach bogatych jednego tylko sektora, tzn. sektora usług. Z drugiej jednak strony brak też podbudowanego teoretycznie zarysu granic owych zmian udziałów. W najbardziej interesujących nas w tym artykule kwestii - skali zmian strukturalnych i ich determinant - trudno znaleźć dobrze uargumentowane oceny w tym względzie. Pisząc o przesunięciach w strukturze w kierunku wzrostu udziału usług, Ronald Schettkat i Lara Yocarini stwierdzili we wstępie, że „brak pełnego zrozumienia czynników, które wpływają na trwałe przesuwanie się zatrudnienia w kierunku sektora usług"8.

Również oficjalne statystyki (krajowe i międzynarodowe) dotyczące sektora usług niewiele mówią o przemianach strukturalnych. Podejmowane indywidualne próby wyodrębnienia pewnych kategorii działalności, które zalicza się do gałęzi o intensywnym wykorzystywaniu kapitału ludzkiego, i ich pomiaru przynoszą trudno porównywalne między sobą wyniki.

Powróćmy jednak do zmian udziału sektorów w PKB i spójrzmy na tabelę 1, która potwierdza istnienie zjawiska krzywoliniowości udziału sektora przemysłu przetwórczego. Przedstawiono w niej zmiany udziału tegoż sektora w krajach zachodnioeuropejskich w okresie niemal półwiecza: 1964-2010.

${ }^{8}$ R. Schettkat, L. Yocarini, The Shift to Services. A Review of the Literature, „Forschungsinstitut zur Zukunft der Arbeit Discussion Papers” 964, December 2003, s. 3. 
Tabela 1

Zmiany udziału przemysłu przetwórczego w PKB

w wybranych krajach zachodnioeuropejskich w latach 1964-2000 [\%]

\begin{tabular}{|l|c|c|c|c|c|c|}
\hline \multirow{2}{*}{ Kraj } & \multicolumn{6}{|c|}{ Rok } \\
\cline { 2 - 7 } & $\mathbf{1 9 6 4}$ & $\mathbf{1 9 7 0}$ & $\mathbf{1 9 8 0}$ & $\mathbf{1 9 9 0}$ & $\mathbf{2 0 0 0}$ & $\mathbf{2 0 1 0}$ \\
\hline Kraje mniejsze: & & & & & & \\
Austria & 33,2 & 33,7 & 28,3 & 19,3 & 18,4 & 17,3 \\
Belgia & 31,1 & 32,1 & 24,5 & $18,2^{a}$ & 17,1 & $12,5^{b}$ \\
Dania & $19,7^{c}$ & 18,5 & 16,4 & 15,0 & 13,9 & 10,5 \\
Finlandia & 21,8 & 24,3 & 25,6 & 19,7 & 24,7 & 16,5 \\
Holandia & $\ldots$ & 29,0 & 23,5 & 17,1 & 13,9 & 11,9 \\
Szwajcaria & $\ldots$ & $\ldots$ & $\ldots$ & 20,4 & 17,9 & 18,1 \\
Szwecja & 27,7 & 25,0 & 21,7 & $16,0^{d}$ & 19,3 & 14,2 \\
& & & & & & \\
Kraje duie: & & & & & & \\
Francja & 29,3 & 28,7 & 26,2 & $\ldots$ & 14,4 & $9,7^{e}$ \\
Niemcy & 39,9 & 38,4 & 33,1 & 25,4 & 20,8 & 18,7 \\
Włochy & 27,6 & 29,0 & 30,5 & 21,2 & 18,6 & 15,0 \\
Wielka Brytania & 30,0 & 28,1 & $22,1^{f}$ & 20,3 & 14,7 & 10,2 \\
\hline
\end{tabular}

$a-1995 b-2009 c-1966 d-1993 e-2009 f-1979$

Źródło: OECD, National Accounts 1964-1981, Paris 1983 oraz OECD, National Accounts at a Glance, 1989-2011. Complete database available via OECD's eLibrary.

Kalkulacje zawarte w tabeli 1 poza tym, że potwierdzają tendencję do zmniejszania się udziału sektora przemysłu przetwórczego, wywołuja jednak więcej pytań, niż oferują odpowiedzi. Widać z nich, że tylko część zmian ma zwiazek z tendencją do krzywoliniowości udziału tego sektora w PKB. Spora część dynamiki zmniejszania się tego udziału sugeruje czasem stopniowe, czasem szybsze słabnięcie pozycji konkurencyjnej poszczególnych krajów.

Trudno bowiem wyjaśnić samą tendencją krzywoliniowości fakt, że np. udział przemysłu przetwórczego Niemiec zmniejszył się w latach 19802010 z 33,1 do 18,7\% PKB, podczas gdy ten udział Francji skurczył się z 26,2 do zaledwie 9,7\%! Mało tego, niektóre kalkulacje pokazują też tendencję odwrotna, gdy po przejściowym ostrym spadku udziału przemysłu przetwórczego udział ten zwiększa się w następnej dekadzie lub dwóch. Najwyraźniej wzrost konkurencyjności przemysłu przetwórczego w przypadku np. Szwecji czy Finlandii zaowocował znaczącym wzrostem udziału tego sektora w PKB, nawet jeśli ten udział następnie powoli znów zaczynał się zmniejszać.

Możemy więc mówić o różnych determinantach udziału przemysłu przetwórczego. Po pierwsze, mamy do czynienia ze słabnąca relatywną pozycja konkurencyjną niektórych krajów w długim okresie. Po drugie, mamy przejściowa poprawę pozycji konkurencyjnej, z reguły w wyniku przeprowadzonych zmian instytucjonalnych (reform) w danym kraju. W rezultacie tej poprawy zwiększa się udział przemysłu przetwórczego w PKB (zwykle też poprawiają się wyniki w eksporcie wyrobów przemysłowych). Po trzecie, i pierwszy, i drugi rodzaj zmian strukturalnych wpisują się jednak w tendencję ogólną 
krzywoliniowości udziału sektora przemysłu przetwórczego. Dlatego że kraje, w których spadek udziału tego sektora jest szybszy niż w krajach o porównywalnym poziomie rozwoju gospodarczego, jak również kraje odzyskujące w wyniku reform pewien, wyższy, poziom konkurencyjności, odnotowują po pewnym czasie kolejne zmniejszenie udziału tego sektora w PKB.

Co nam mówią oficjalne statystyki o udziale sektora usług, poza tym, że udział ten rośnie i że najwyraźniej ten wzrost udziału jest pozytywnie skorelowany ze wzrostem zamożności, mierzonej PKB per capita? Niewiele. Jeśli chcemy znaleźć użyteczne dane, analizy empiryczne i teoretyczne rozważania, to zdać się musimy na nieliczne artykuły i materiały robocze różnych instytucji. I tak np. w serii takich materiałów badano udział kapitału niematerialnego (intangible capital) w PKB i jego składników ${ }^{9}$. Udział kapitału niematerialnego, w odróżnieniu od tego udziału kapitału materialnego (tangible capital), czyli - jak do tej pory się to określa w urzędowych statystykach - kapitału lub kapitału trwałego (fixed capital), to w znacznej mierze terra incognita. Owszem, już szereg lat temu wprowadzono do rachunków narodowych jako składnik kapitału informatyczny software, a od 2013 r. w tych rachunkach w USA traktuje się B+R jako inwestycje. Ale od tego daleko jeszcze do zrozumienia dynamizujacej roli kapitału niematerialnego, w różnych jego formach, jako czynnika wzrostu gospodarczego i wzrostu wydajności, zwłaszcza w sektorze usług.

Posłużę się przykładem z sektora przemysłu przetwórczego. Z badań szwedzkich firm tego przemysłu, przeprowadzonych w latach siedemdziesiątych XX w., wynikało, że zmiany techniczne wprowadzane do produkcji wnosiły od $20-30 \%$ do $60-70 \%$ wkładu w zagregowany wzrost wydajności. Całą resztę wnosiły przeprowadzane równolegle ze zmianami technicznymi zmiany organizacyjne i inne ${ }^{10}$. Tak więc innowacja technologiczna, często produkt prac badawczych i rozwojowych $(\mathrm{B}+\mathrm{R})$, nie była wyłącznym źródłem wzrostu wydajności. Inne czynniki wnosiły nieraz tyle samo lub nawet więcej niż sama zmiana techniczna.

Wspomniani wyżej autorzy ${ }^{11}$ prezentują składniki kapitału niematerialnego i ich rolę we wzroście gospodarczym i wzroście wydajności, a następnie dokonuja próby ich pomiaru. Tak więc zwracaja oni uwagę, że inwestycje $\mathrm{w}$ kapitał niematerialny stanowia odpowiednik inwestycji w kapitał materialny (kapitał trwały) i również dynamizują wzrost gospodarczy. Wydatki na software, B+R, reklamę, szkolenie personelu, na powiększanie kapitału organizacyjnego firm itd. mają decydujacce znaczenie dla utrzymania i poprawy pozycji rynkowej firm w przyszłości w nie mniejszym stopniu niż wydatki

${ }^{9}$ Zob. zwłaszcza C. A. Corrado, C. R. Hulten, D. E. Sichel, Intangible Capital and US Economic Growth, „Review of Income and Wealth” 55, 2009, nr 3, s. 661-685; B. van Ark et al., Meas-uring Intangible Capital and its Contribution to Economic Growth, „EIB Papers” 14, 2009, $\mathrm{nr}$ 1, s. 62-93; K. Uppenberg, H. Strauss, Innovation and Productivity Growth in the EU Services Sector, European Investment Bank, EIB Paper, July 2010.

${ }^{10}$ Zob. B. Carlsson, The Content of Productivity Growth in Swedish Manufacturing, „Research Policy" 10, 1981, nr 4.

${ }^{11}$ B. van Ark et al., op. cit. 
na kapitał materialny. Wyróżniają oni trzy szeroko pojmowane kategorie wydatków tworzących kapitał niematerialny (inwestycje w kapitale niematerialnym):

1. Skomputeryzowana informacja (w tym: software i bazy danych);

2. Innowacje będące własnością firmy (w tym: badania naukowe i rozwojowe, czyli tradycyjne $\mathrm{B}+\mathrm{R}$, ale także inne badania, takie jak m.in. poszukiwania i szacunki zasobów mineralnych, prawa autorskie i koszty nabycia tych licencji, prace przy tworzeniu nowych produktów w branży finansowej, inżynieryjne i architektoniczne prace projektowe); oraz

3. Kompetencje ekonomiczne (prace podnoszace wartość marki danej firmy, wewnątrzfirmowe podnoszenie poziomu kapitału ludzkiego w postaci różnego rodzaju szkoleń, a także prace związane z adaptacjami organizacyjnymi $\mathrm{w}$ firmie w odpowiedzi na pojawiające się wyzwania).

Powzięta przez powyższych autorów próba zmierzenia kapitału niematerialnego wymagała wypracowania metodologii liczenia powyższych kategorii kosztów. Dopiero po dokonaniu tych prac mogli oni przystapić do właściwego pomiaru, który przedstawiamy w tabeli 2.

Tabela 2

Inwestycje w kapitał niematerialny w sektorze przedsiębiorstw w wybranych krajach OECD według danych z 2006 r. [w \% PKB]

\begin{tabular}{|l|c|c|c|c|}
\hline \multirow{2}{*}{ Kraj } & \multicolumn{3}{|c|}{ Kategoria inwestycji } \\
\cline { 2 - 5 } & $\begin{array}{c}\text { Skomputery- } \\
\text { zowana } \\
\text { informacja }\end{array}$ & $\begin{array}{c}\text { Innowacje } \\
\text { własnościowe }\end{array}$ & $\begin{array}{c}\text { Kompetencje } \\
\text { ekonomiczne }\end{array}$ & $\begin{array}{c}\text { Inwestycje } \\
\text { ogółem }\end{array}$ \\
\hline Hiszpania & 0,79 & 2,78 & 1,90 & 5,47 \\
Włochy & 0,64 & 2,21 & 2,19 & 5,04 \\
Niemcy & 0,73 & 3,59 & 2,84 & 7,16 \\
Francja & 1,42 & 3,18 & 3,30 & 7,90 \\
Wielka Brytania & 1,55 & 3,16 & 5,84 & 10,54 \\
USA & 1,61 & 4,37 & 5,50 & 11,48 \\
\hline
\end{tabular}

Źródło: B. van Ark et al., op. cit., s. 69.

Autorzy odnotowują pojawienie się także i innych prac stosujących tę lub zbliżoną metodologię liczenia inwestycji w kapitał niematerialny w stosunku do poszczególnych krajów (Dania, Szwecja, Finlandia, Austria, Grecja, Czechy, Słowacja). Warto jednak podkreślić podobieństwo wyników z punktu widzenia relacji poziomu rozwoju gospodarczego mierzonego PKB per capita i poziomu inwestycji w kapitał niematerialny. Istnieje wyraźna pozytywna korelacja między jedna a druga zmienna (zob. wykres 5). Istnieje też pozytywna korelacja inwestycji w kapitał niematerialny z udziałem sektora usług w PKB. Sugeruje to zreszta tabela 2, która pokazuje, że najwyższy udział inwestycji w kapitał niematerialny odnotowują Stany Zjednoczone i Wielka Brytania - kraje o najwyższym udziale sektora usług w PKB i zatrudnieniu. 
Wykres 5

Zależność między inwestycjami niematerialnymi a PKB per capita w wybranych krajach zachodnich

$\operatorname{PKB}(\%)$

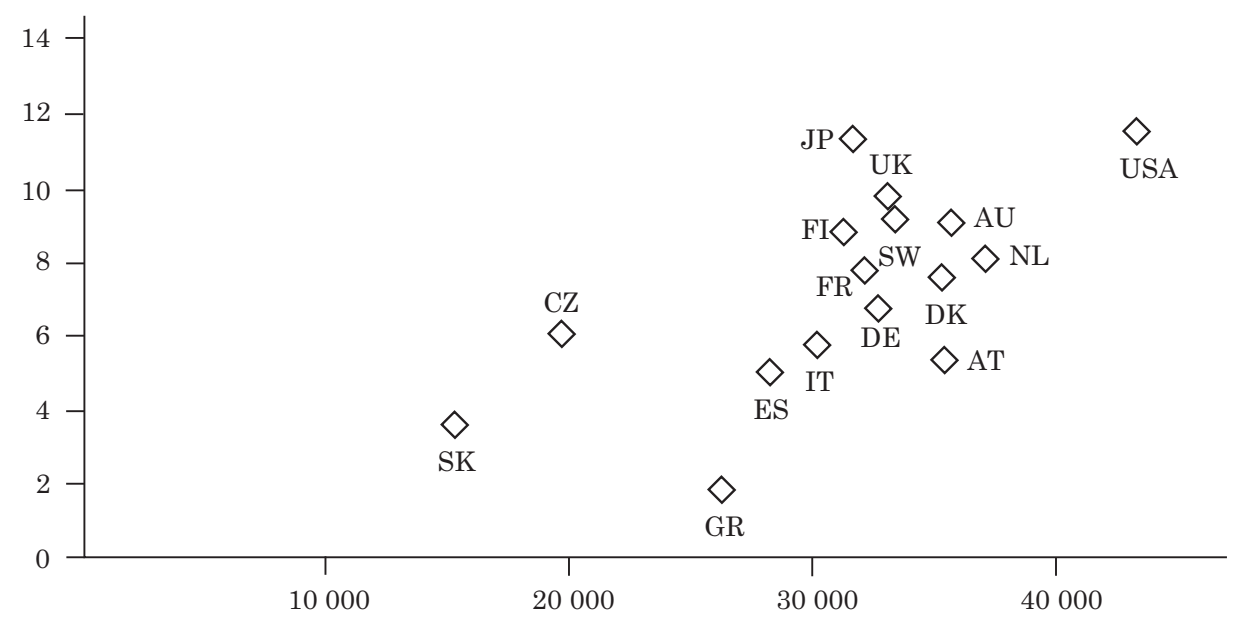

PKB per capita (w USD, według parytetu siły nabywczej, 2001-2004)

Skrócone nazwy państw podano w języku angielskim.

Źródło: B. van Ark et al., op. cit., s. 80.

Kapitał materialny (trwały) występuje we wszystkich sektorach gospodarki w różnych proporcjach. Te różnice dotyczą także różnic wewnątrzsektorowych pomiędzy poszczególnymi gałęziami gospodarki. Podobnie wygląda dystrybucja kapitału niematerialnego, w tym także wewnatrz sektora usług. Niektóre gałęzie sektora usług wykazuja się wysokim udziałem inwestycji $\mathrm{w}$ kapitał niematerialny w PKB i to one tworza ten (sub)sektor usług intensywnie wykorzystujący kapitał ludzki, dynamizujaccy wzrost gospodarczy oraz interesujące nas tutaj zmiany strukturalne. W szczególności zaś tę drugą fazę przekształceń strukturalnych, czyli przesunięcie się roli dominującego sektora gospodarki z przemysłu do usług.

Przyjmowane przez różne organizacje i poszczególnych badaczy klasyfikacje sektora usług z punktu widzenia ich nasycenia kapitałem ludzkim oraz efektów tegoż nasycenia różnią się, jak to już podkreślono wyżej. Jedną z nich jest niedawna klasyfikacja Eurostatu, która definiuje działalności określane łącznie jako „usługi o wysokim nasyceniu wiedzą" (Knowledge Intensive Services - KIS). Sa to usługi informatyczne, telekomunikacyjne, transportowe, a także $\mathrm{B}+\mathrm{R}$ i usługi inżynieryjne. $\mathrm{Z}$ dokonanych kalkulacji wynika, że ich udział w usługach ogółem sięgał w 2005 r. 30-40 punktów procentowych w krajach OECD i w perspektywie dekady wykazywał tendencję wzrostowa (zob. wykres 6). Jednakże inne klasyfikacje, np. włączające całość lub część usług branży finansowej, a wyłączające część branży transportowej, mogłyby przynieść nieco inne proporcje. 
Wykres 6

Udział usług o wysokim nasyceniu wiedzą (KIS) w usługach ogółem

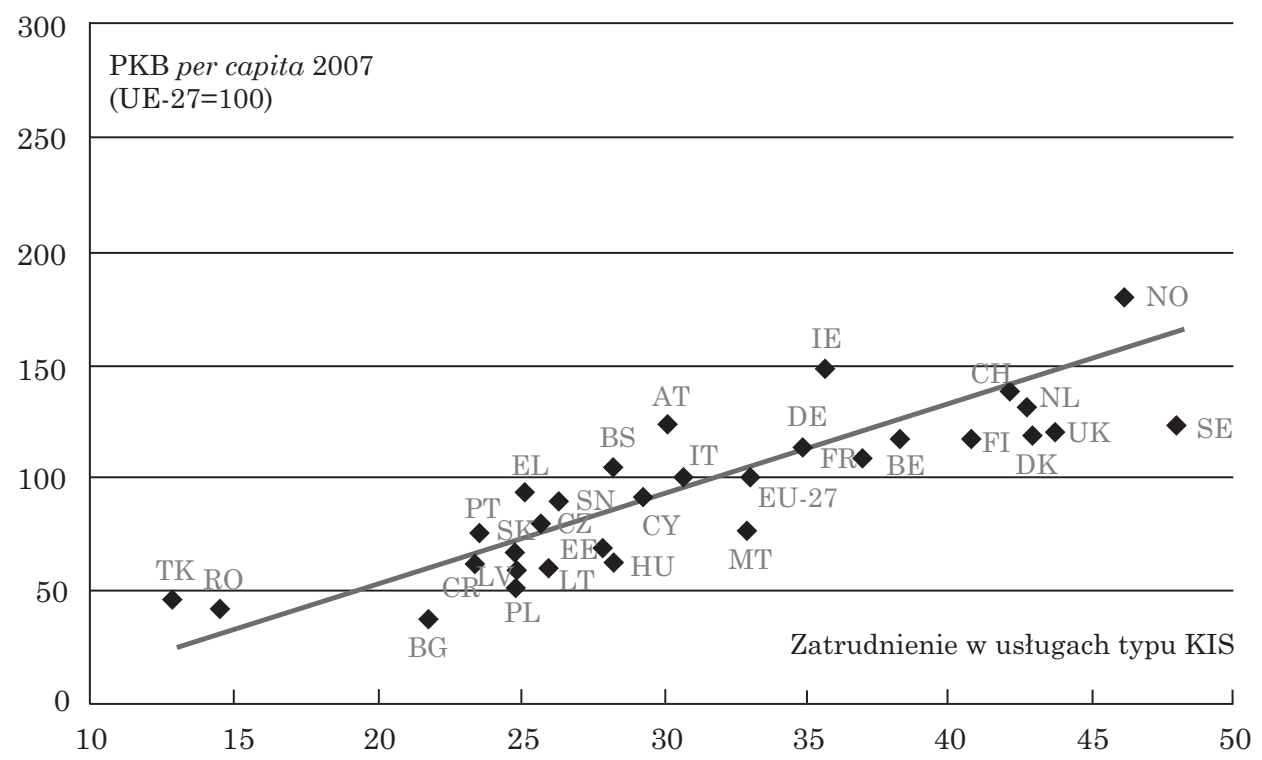

Skrócone nazwy państw podano w języku angielskim.

Źródło: K. Uppenberg, H. Straus, op. cit., s. 43.

Warto wskazać na jeden jeszcze problem związany z mierzeniem sektora usług i jego subsektora dynamizującego wzrost gospodarczy oraz przekształcenia strukturalne. Otóż powyżej przedstawiane analizy dotyczą usług w sektorze przedsiębiorstw, czyli tego, w którym możliwa jest kalkulacja nakładów/ efektów oraz wydajności. Nie dotyczą one usług publicznych (tzw. w Polsce sektora budżetowego czy też „budżetówki”), których udział w PKB mierzony jest tylko według kosztów, głównie płacowych.

Ciagle jesteśmy bardzo daleko od jakiejś akceptowalnej precyzji pomiaru, która pozwoliłaby określić: a) skuteczność osiagania celów oraz b) efektywność osiagania celów w relacji do zaangażowanych środków ${ }^{12}$. Tak więc we wszelkich analizach wewnątrz- i międzysektorowych sektor publiczny jest zauważalny głównie w obszarze zatrudnienia. Nie wnosi to jednak nic do naszych rozważań o dynamizującej roli subsektora usług o wysokim nasyceniu kapitałem ludzkim w tworzenie PKB i wzrost wydajności.

${ }^{12}$ Chociaż warto zasygnalizować pionierski artykuł znanych specjalistów finansów publicznych, zob. A. Afonso, L. Schuknecht, V. Tanzi, Public Sector Efficiency: An International Comparison, „Public Choice” 2005, June, na temat skuteczności w relacji do ponoszonych kosztów mierzonych udziałem w PKB. 


\section{DETERMINANTY DRUGIEJ FAZY PRZEKSZTAŁCEŃ STRUKTURALNYCH}

Próbę sformułowania ogólnego wzorca wzrostu udziału i (na wysokim poziomie rozwoju gospodarczego) dominacji sektora usług w PKB i zatrudnieniu rozpocząć należy, zdaniem autora, od pewnych ogólnych prawidłowości dotyczących wszystkich trzech sektorów. Otóż najsilniej przemawiają do autora wnioski i przewidywania sformułowane przez badaczy uważanych za klasyków tej problematyki: Colina Clarka czy Jeana Fourastiégo.

Tak więc ten pierwszy argumentował, że popyt końcowy będzie się przesuwać w rosnaccym stopniu w kierunku usług, zwiększając nie tylko ich udział w PKB, lecz także w zatrudnieniu ${ }^{13}$. Przewidywane przesunięcia wiązał on z koncepcja hierarchii potrzeb (najbardziej znana wersja to koncepcja Abrahama Maslowa, przedstawiona po raz pierwszy w 1943 r.). Usługi zaspokajaja wyższe potrzeby w większym stopniu niż dobra materialne i dlatego - w miarę wzrostu dochodów - rosnąca ich część będzie przeznaczana na zaspokajanie tychże potrzeb wyższego rzędu.

Z kolei Fourastié zauważał ówczesne niższe tempo wzrostu wydajności w usługach niż w przemyśle i traktował tę różnicę, wraz ze zmianami w popycie na usługi, jako źródło wzrostu zatrudnienia w usługach w drugiej połowie $\mathrm{XX} \mathrm{w.}{ }^{14}$

Obserwacje Fourastiégo w kwestii niższego tempa wzrostu wydajności w usługach stanowia pomost do przeciwstawnych teorii. Najbardziej znana spośród tych ostatnich jest teoria Williama Baumola, który utrzymywał, że nie ma w istocie wzrostu popytu na usługi, są tylko coraz wyższe ceny usług związane z niższym tempem wzrostu wydajności, a także z presją w kierunku jednakowego tempa wzrostu płac, niezależnie od wydajności ${ }^{15}$. Teoria nie do utrzymania w warunkach m.in. rosnacego popytu na usługi konsumenckie ze strony gospodarstw domowych, w których pracuje oboje małżonków, czy pojawiania się nowych kategorii usług producenckich i konsumenckich.

Koncepcję Clarka i Fourastiégo można nazwać koncepcją popytową. Autor niniejszego artykułu chciałby jednak zwrócić uwagę także na stronę podażowa, opartą na historii gospodarczej. Otóż zmiany strukturalne w procesie rozwoju w całej historii gospodarczej wskazują na pojawianie się nowych specjalizacji. W odniesieniu do pierwszej fazy, tzn. industrializacji, wyłanianie się specjalizowanej produkcji zaczynało się od utalentowanych rolników, którzy obok swej zasadniczej działalności produkcyjnej wykonywali dzięki swym umiejętnościom inne prace na zamówienie członków wiejskiej społeczności lub feudalnych władców.

Porzucali oni w pewnym punkcie czasowym swoją działalność rolnicza i koncentrowali się na wytwarzaniu produktów rzemiosła (kowale, cieśle i sto-

13 C. Clark, Conditions of Economic Progress, MacMillan, London 1951.

14 J. Fourastié, La grand espoir du XX $X^{e}$ siècle, Presses Universitaires de France, Paris 1949.

15 Zob. zwłaszcza W. J. Baumol, Macroeconomics of Unbalanced Growth: The Anatomy of Urban Crisis, „American Economic Review” 57, 1967, June, s. 415-426. 
larze meblowi i wielu, wielu innych). Najczęściej też przenosili się do miast, gdzie stawali się wolnymi ludźmi, osiagając status rzemieślnika. Później, od XVII-XVIII w., najbardziej przedsiębiorczy spośród nich tworzyli manufaktury, dając początek specjalizacji przemysłowej. Tak więc ten proces trwa już ponad tysiąc lat. Jeszcze na przełomie XIX i XX w. wiejski majsterklepka Henry Ford zrobił to samo - z oszałamiajacym sukcesem.

Otóż autor niniejszego opracowania utrzymuje, że dokładnie taki sam proces ma miejsce w przypadku powstawania firm usługowych. Zakładane sa one często przez ludzi, którzy wykonywali pracę o charakterze usługowym w firmach przemysłowych, lecz doszli do wniosku, że będą mogli bardziej efektywnie wykonywać swą pracę, gdy będą s pecjalizow ać się w usługach - świadczyć je różnym firmom przemysłowym.

Ten proces nigdy się nie kończy. Z różnych badań wynika, że współcześnie $\mathrm{w}$ firmach przemysłowych pewien procent pracowników wykonuje prace o charakterze usługowym, a w usługach pewien procent pracowników wykonuje prace o charakterze produkcyjnym ${ }^{16}$. Dla nas $\mathrm{w}$ tym artykule ważne jest jednak, że rośnie popyt na usługi, w tym na usługi o wysokim nasyceniu kapitałem ludzkim. Jak stwierdzono w poprzedzającej części artykułu, popyt na te ostatnie rośnie szybciej niż zagregowany popyt na usługi.

Do wyjaśnień popytowych i podażowych warto dodać jeszcze jedną determinantę, mianowicie wpływ konkurencji międzynarodowej w otwartej gospodarce światowej. Otóż drugą stroną medalu, w tym przypadku wzrostu poziomu zamożności, sa wysokie płace i związane z tym wysokie koszty pracy (dodatkowo powiększane przez rosnące obciążenia socjalne). Powoduje to osłabienie pozycji konkurencyjnej krajów zamożnych w odniesieniu do produktów przemysłu przetwórczego. W szczególności dotyczy to produktów, których wytwarzanie stało się łatwe do opanowania, a same produkty stały się standaryzowanymi (w literaturze ekonomicznej w języku angielskim używa się terminu: commoditization, od terminu; commodity, którym określa się dobra nieprzetworzone: surowce, paliwa i artykuły rolne).

W rezultacie utraty konkurencyjności kraje zamożne wycofują się więc z produkcji prostych, a stopniowo nawet bardziej zaawansowanych wyrobów przemysłu przetwórczego i przesuwają się w kierunku świadczenia usług, wymagających większego wkładu kapitału ludzkiego. Czynią to nie tylko pracownicy zamykanych, niekonkurencyjnych zakładów produkcyjnych, lecz także całe przedsiębiorstwa. Uppenberg i Strauss ${ }^{17}$ podaja jako przykład IBM, który dzisiaj jest w większej mierze firmą usługowa, oferująca swoim klientom rozwiązania problemów biznesowych niż komputerowy hardware. Innym, ze zbliżonej branży, przykładem może być decyzja firmy Ericsson o sprzedaży swoich udziałów w produkcji telefonów komórkowych swemu partnerowi $\mathrm{w}$ joint venture i koncentracji własnej oferty na tworzeniu, wdrażaniu i szkoleniu z zakresu systemów telekomunikacyjnych. W każdym takim przypadku zmiana profilu działalności firmy wynika z przekonania, że w nowym obszarze

${ }^{16}$ Zob. np. US Department of Commerce, Service industries and economic performance, Washington, DC, 1996.

${ }^{17}$ Ibidem, s. 15 . 
konkurowania na rynku lepiej wykorzysta się posiadane przewagi, w szczególności wyższy poziom kapitału ludzkiego i inne kompetencje, będące najczęściej pochodną tego wysokiego poziomu kapitału ludzkiego.

W tym punkcie naszej prezentacji dochodzimy do kwestii najrzadziej dyskutowanej w kontekście zmian strukturalnych, zwłaszcza drugiej fazy tych przekształceń. Otóż powyższe argumenty dotyczące przesunięć w strukturze wytwórczości w kierunku owych usług nasyconych kapitałem ludzkim nie powinny prowadzić do wniosku, że jest to proces deterministyczny. Czyli że każdy kraj kiedyś dojdzie do tego poziomu zamożności i takiej struktury produkcji, jakie dzisiaj rejestrują Stany Zjednoczone. Nic bardziej błędnego! Doświadczenia z industrializacją pokazuja, że sukces zależy od jakości instytucji i polityki prowadzonej w ramach tych instytucji. Muszą one być przynajmniej dostateczne (good enough, patrz cytowany już Fukuyama!), by ten sukces został osiagnięty.

Hipoteza autora tego artykułu zakłada, że w przypadku drugiej fazy przekształceń strukturalnych poprzeczka wymagań instytucjonalnych ustawiona jest wy ż ej niż w przypadku industrializacji. Do tej konkluzji prowadzi autora przekonanie, iż wymagania pracowników o wysokim kapitale ludzkim oraz rodzaje prowadzonej przez nich działalności zawodowej wymagają wyższej niż tylko dostateczna jakości instytucji i polityki: większego zakresu wolności gospodarczych, ale także wolności obywatelskich i w jakimś stopniu także wolności politycznych.

Autor niniejszego pisał już wcześniej, że same ekonomiczne wolności nie wystarcza. Nawet najprecyzyjniej sformułowane regulacje dotyczace praw własności i procedury wymiaru sprawiedliwości chroniące te prawa nie wystarcza, gdy brak elementarnego bezpieczeństwa własności prywatnej i bezpieczeństwa jej właścicieli, gdy brak elementarnego ładu i porządku. Sprawa rosyjskiego prawnika Magnitskiego i przejęcie typu mafijnego majątku firmy, dla której pracował on w Rosji, sa dobrym przykładem problemów z prawami obywatelskimi i politycznymi, które zderzają się z korupcją w gospodarce, wśród urzędników, w policji i w wymiarze sprawiedliwości ${ }^{18}$.

Podobnie sprawa ma się z kwestią zaufania do stabilności reguł gry w gospodarce czy pewności ochrony praw obywatelskich. Wreszcie, nie bez znaczenia jest także poczucie pewności, że nie obudzimy się rano któregoś dnia, aby dowiedzieć się o zmianie systemu na taki, w którym to, co było zgodne z prawem wczoraj, dzisiaj już nie jest. Mało tego, wbrew zasadzie lex retro non agit możemy zostać pociagnięci do odpowiedzialności za to, co zrobiliśmy, czy nawet powiedzieliśmy, wczoraj.

Stawiam tezę, że to właśnie inwestycje w kapitał niematerialny w większym stopniu niż inwestycje w kapitał materialny wymagaja wysokiego poziomu wolności ekonomicznych, obywatelskich i politycznych. Wolność badań naukowych (w tym badań dla gospodarki) dotyczy zapewne badań ważnych dla wszystkich sektorów gospodarki. Ale już takie inwestycje w kapitał nie-

${ }^{18}$ O tego rodzaju problemach zob. J. Winiecki, Private Sector after Communism, Routledge, London 2004 (rozdz. 2) oraz idem, Russia and China Facing the 'Great Wall', „Post-Communist Economies" 24, 2012, nr 3. 
materialny, jak prawa autorskie i licencje na ich wykorzystywanie, projekty architektoniczne dla władz publicznych, prace nad produktami w bankach i innych firmach finansowych, wymagaja większej swobody twórców. Tym bardziej dotyczy to inwestycji niematerialnych w obszarze kompetencji ekonomicznych, w tym także kwestii reklamy czy rozwijania umiejętności określanych czasem jako kapitał organizacyjny.

I wreszcie, potrzeba najtrudniejsza do empirycznego zbadania, czyli poczucie wolności. Całkowicie niezależnie od konkretnych przedsięwzięć w obszarze kapitału niematerialnego, sukces tych przedsięwzięć zależy w niemałej mierze od tego, czy ci, którzy tym się zajmuja, nie muszą się zastanawiać, czy to, co powiedzą w luźnej dyskusji wokół interesujących ich spraw, nie będzie miało dla nich negatywnych konsekwencji w postaci takich czy innych represji. We wzmiankowanym wcześniej artykule: Russia and China Facing the 'Great Wall' zwracam uwage m.in. na to właśnie zagadnienie. Warto w tym kontekście podkreślić, że Dolina Krzemowa powstała w USA, natomiast nie udało się to ani w Rosji sowieckiej, ani w postsowieckiej. Przyczyn tego stanu rzeczy doszukuję się właśnie w braku owego wyższego poziomu wolności gospodarczych, obywatelskich i politycznych. I tu warto przypomnieć raz jeszcze moją ocenę poglądu Fukuyamy w odniesieniu do procesu rozwoju gospodarczego. Do sukcesu drugiej fazy przekształceń strukturalnych procesu rozwoju ten jego dostateczny poziom jakości instytucji i polityki już nie wystarcza.

Warto też odwołać się do wielce interesujaccych badań empirycznych Antonia Fatása i Iliana Mihova. Autorzy ci przebadali liczną grupę krajów pod względem związków między tym, co określają terminem: jakość instytucjonalna, a poziomem PKB per capita. Wykres 7 przedstawia wykres rozrzutu (scattergram) wyznaczający miejsca poszczególnych krajów względem obu tych zmiennych ${ }^{19}$.

Autorzy stwierdzają istnienie korelacji między zmiennymi, ale dostrzegaja, że związek ten jest słaby dla niskiego i średniego poziomu dochodów (poniżej 10-12 tys. USD), natomiast jest silny i pozytywny na wyższych poziomach PKB na mieszkańca. Interpretują to w ten sposób, że jakość instytucjonalna zaczyna ważyć znacznie bardziej dopiero powyżej pewnego poziomu dochodów. Chociaż nie wiążą tego expressis verbis ze sformułowaną wyżej przez autora niniejszego artykułu tezą o znaczeniu wolności ekonomicznych, obywatelskich i politycznych na wyższym poziomie rozwoju, to jednak wnioski zmierzają wyraźnie w tym kierunku.

Co interesujace, wnioski Fatása i Mihova oraz sam scattergram wspierają wyrażona później niż ich artykuł tezę Fukuyamy, że jakość instytucji i polityki może być tylko dostateczna (good enough) dla sukcesu industrializacji, czyli pierwszej fazy przekształceń strukturalnych. Ale także wspieraja stwierdzenia autora tego artykułu, że dla sukcesu drugiej fazy przekształceń strukturalnych ta dostateczna jakość już nie wystarcza.

19 A. Fatás, I. Mihov, Another Challenge to China's Growth, „Harvard Business Review” 2009, nr 23. Zob. także http://fatasmihov.blogspot.com/2009/03. 
Wykres 7

Jakość instytucjonalna a poziom PKB per capita

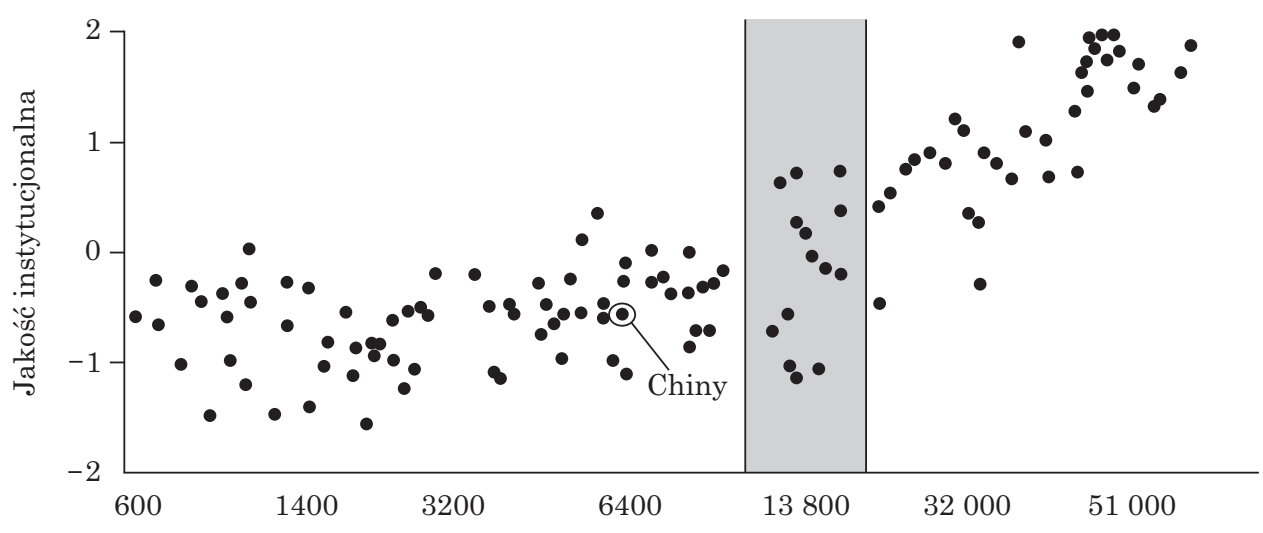

PKB per capita (2007, w USD), skala logarytmiczna

Źródło: na podstawie A. Fatás, I. Mihov, op. cit.

Warto przypomnieć w tym miejscu wykres 4 powyżej i związany z nim niepokój autora, że jakkolwiek pokazuje on pozytywną korelację między wolnościami gospodarczymi i PKB per capita, to jednak zbyt wiele jest krajów, które wyraźnie odbiegają od linii trendu. Wykres 7 wzięty z tekstu Fatása i Mihova wyjaśnia nam, dlaczego tak się dzieje. Fatás i Mihov bowiem wskazują na istnienie przedziału dochodu PKB na mieszkańca (ok. 10-12 tys. USD), który nazywaja „wielkim murem” - stanowi on barierę dla krajów, których jakość instytucji jest niewystarczająca. Jeśli nie poprawią jakości tych instytucji, grozi im ugrzęźnięcie na owym średnim poziomie rozwoju. Tak więc linia trendu z wykresu 4 powinna zostać zastapiona dwiema liniami trendu: jedna wykazująca słaby związek dla krajów mniej zamożnych (znajdujących się przed „wielkim murem”) i drugą wykazująca silny związek dla krajów zamożnych (znajdujących się już za „wielkim murem”).

Termin: „wielki mur” jest aluzją do Chin właśnie, gdyż ci dwaj autorzy uważają - i słusznie! - że Chinom, jeśli nie nastapi znaczaca poprawa jakości chińskich instytucji, może grozić takie właśnie ugrzęźnięcie na średnim poziomie. Znajdujemy więc także pośrednie potwierdzenie naszej tezy o potrzebie wolności ekonomicznych, obywatelskich i politycznych dla osiagnięcia statusu zamożnej gospodarki. Czym innym bowiem jest jakość instytucjonalna, jak nie odbiciem stanu rządów prawa, stabilności politycznej, ochrony własności prywatnej i innych aspektów wolności gospodarczych, obywatelskich i politycznych? Z perspektywy celów tego artykułu ta wysoka jakość instytucji stanowi determinantę zmian w strukturze gospodarki w drugiej ich fazie, tzn. dominującej roli sektora usług, z usługami wymagającymi wysokiego nasycenia kapitałem ludzkim jako silnikiem wzrostu gospodarczego.

dr hab. Jan Winiecki

Profesor Wyższej Szkoty Informatyki i Zarzadzania w Rzeszowie winiecki@neostrada.pl 


\title{
STRUCTURAL TRANSFORMATIONS IN ECONOMIC DEVELOPMENT: INTERPRETATIONS AND EXTENSIONS
}

\author{
Summary
}

Economies not only grow, but also change their output structure in the process. Although structural changes take place throughout the whole process of economic development, the author identifies certain phases of that process, which in his opinion are of particular significance. They are: industrialisation (a shift in the development engine role from agriculture to industry) and an emerging engine role of human capital-intensive services (a shift of dominance from industry to services).

The first of these phases has been intellectually much better researched than the second. There are numerous researches that prove general standardised patterns of structural transformation as well as differences between them. The author notes that the inflection point, when the share of the manufacturing sector reaches its maximum level (between $30 \%$ and $40 \%$ GDP), is probably somewhat overstated, given various distortions generated by activist developmental strategies. Also, he points out to the studies that place the beginning of intensive growth (growth on per capita basis) in poor countries at a much earlier date than it would arise from the established literature sources.

The second phase is less well recognised both theoretically and empirically. There are no 'fixed' issues and the theoretical part, as well as the empirical, are at the very early stage of development. The only certain fact, or constant, is the positive correlation between the level of development (in terms of GNP p.c.) and the share of human capital-intensive services calculated in different ways.

The author's contribution to the study of the second phase of transformations concerns the link between the level of GNP p.c. and the level of economic and civic freedoms. It is stressed that while in the industrialisation process the correlation between the two variables is weak, it is much stronger in the second major phase of emerging dominance of human capital-intensive services. 
Copyright of Journal of Law, Economics and Sociology is the property of Faculty of Law and Administration of Adam Mickiewicz University in Poznan and its content may not be copied or emailed to multiple sites or posted to a listserv without the copyright holder's express written permission. However, users may print, download, or email articles for individual use.

Właścicielem praw autorskich do „Ruchu Prawniczego, Ekonomicznego i Socjologicznego” jest Wydział Prawa i Administracji Uniwersytetu im. Adama Mickiewicza w Poznaniu. Zawartość czasopisma nie może być kopiowana, przesyłana do innych stron internetowych bądź zamieszczana na blogach bez pisemnej zgody wydawcy. Niemniej artykuły można drukować, kopiować lub przesyłać w formie elektronicznej na własny użytek. 